\title{
Low concentration fertigation solution allows greater macronutrient use efficiency in coffee seedlings
}

\author{
Kelly Martins Rosa1 (iD, Paulo Eduardo Branco Paiva² (i), Victor Peçanha de Miranda Coelho² (D), \\ Mychelle Carvalho ${ }^{2}$ (D), Henrico Luis Bizão de Assis ${ }^{3}$ (iD)
}

${ }^{1}$ Horta Rio Grande, Frutal, MG, Brasil

${ }^{2}$ Instituto Federal de Educação, Ciência e Tecnologia do Triangulo Mineiro/IFTM, Campus Uberaba, Uberaba, MG, Brasil

"Universidade Estadual Paulista "Júlio de Mesquita Filho"/UNESP, Campus Jaboticabal, Jaboticabal, SP, Brasil

Contact authors: kellymartinsrosap@gmail.com; paulopaiva@iftm.edu.br; victorcoelho@iftm.edu.br; mychellecarvalho@iftm.edu.br; henricoassis@hotmail.com Received in July 5, 2021 and approved in November 19, 2021

\section{ABSTRACT}

Coffee seedling production in cone-shaped containers and substrate results in lower sanitary risk and costs. With the use of small containers and substrates with low fertilizer levels, fertigation is necessary for seedling development. An experiment was carried out with three macronutrient concentrations (electrical conductivities of 1.0, 2.0 and $3.0 \mathrm{dS} \mathrm{m}^{-1}$ ) and a non-fertilized control using Coffea arabica cv. Topázio seedlings in $50 \mathrm{~cm}^{3}$ cone-shaped containers and composted pine bark-based substrate. The following fertilizers (expressed in $\mathrm{g} \mathrm{m}^{-3}$ of water) were used in the nutrient solution with EC of $1.0 \mathrm{dS} \mathrm{m}^{-1}: \mathrm{Ca}\left(\mathrm{NO}_{3}\right)_{2}(400), \mathrm{KNO}_{3}(250), \mathrm{MgSO}_{4}(175),\left(\mathrm{NH}_{4}\right) \mathrm{PO}_{4}(50)$ and ConMicros Standard ${ }^{\circ}(25)$. In the solutions with 2.0 and 3.0 dS $\mathrm{m}^{-1}$, macronutrient concentration was doubled and tripled, while micronutrients remained the same. At four months we assessed $\mathrm{EC}$ and $\mathrm{pH}$ of the solution drained, shoot dry mass, shoot nutrient concentration and accumulation and macronutrient use efficiency. Fertigation with 1.0 and $2.0 \mathrm{dS} \mathrm{m}^{-1}$ produced seedlings with greater mass $(+10 \%)$ than fertigation with $3.0 \mathrm{dS} \mathrm{m}^{-1}$, while higher macronutrient supplies increased shoot $\mathrm{N}, \mathrm{P}, \mathrm{K}, \mathrm{Mg}$ and $\mathrm{S}$ concentration. Fertigation with $2.0 \mathrm{dS} \mathrm{m}^{-1}$ caused greater shoot $\mathrm{N}, \mathrm{P}, \mathrm{K}$ and $\mathrm{Ca}$ accumulation and this conductivity also resulted in higher accumulation of B, Fe, Mn and Zn without increasing the micronutrient supply. The response to the increase in $\mathrm{Ca}$ in the nutrient solution is evident in the accumulation of this nutrient in the plant but not its concentration, possibly due to the dilution effect. Micronutrient accumulation in this species is also more adequate for determining nutritional status than the concentration in the plant. The least concentrated macronutrient solution increases nutrient use efficiency in $C$. arabica seedlings as well as being economically and environmentally more sustainable.

Key words: Coffea arabica; Electrical conductivity; pH; Nutrition; Substrate.

\section{INTRODUCTION}

Coffee seedling production in Brazil uses a mixture of soil and organic matter in plastic bags and substrate in coneshaped containers. The traditional method involves mixing soil and manure at a proportion of 70:30 with chemical fertilizers in plastic bags (Gonçalves et al., 2009). When agricultural substrates are used in cone-shaped containers, their composition and the size of the container should be considered.

The advantages of the system with cone-shaped containers and substrate are the absence of phytonematodes, lower risk of pathogens, less labor and reduced nursery space. Agricultural substrates are porous materials that provide good support for root growth and generally consist of composted pine bark or coconut fiber with adequate water holding capacity and porosity for plants.

Most agricultural substrates have added fertilizers, but nutrients are quickly lost after irrigation, requiring nurseries to use fertilization in seedling production. The two most common types of fertilization in substrates are slow- and controlledrelease fertilizers and fertigation. Slow- and controlled-release fertilizers are practical because mixing them with the substrate before planting guarantees the supply of nutrients for months. However, nutrient release can vary over time and depends on uncontrollable factors such as temperature (Adams; Frantz; Bugbee, 2013). Fertigation makes possible to manage seedling nutrition throughout its development, thereby reducing heterogeneous availability and leaching losses (Coelho et al., 2018). Moreover, fertigation is cheaper than slow-release fertilizers (Silva et al., 2020).

Coffee seedling nutrition studies have been conducted primarily with nutrient solutions in closed systems (hydroponic) (Flores et al., 2016; Carr; Boaretto; Mattos, 2020). Most seedling production systems experience nutrient losses caused by leaching and these depend on irrigation, the container, substrate and fertilizers. Little is known about these losses. With soluble fertilizers, losses of $\mathrm{P}$ and $\mathrm{K}$ are higher than those with controlled-release fertilizers and $\mathrm{N}$ losses are similar (Broschat, 1995). Contrary to expected, K losses are greater with slow-release fertilizers compared to fertigation; for $\mathrm{N}$ and $\mathrm{P}$, leaching losses are similar (Boaventura et al., 2004)

As with the assessment of the nutritional status of coffee plants, analysis of plant tissue nutrients has been considered for seedlings. Gonçalves et al. (2009) proposed critical leaf macronutrient concentration ranges for coffee seedlings in a study of increasing doses of fertilizers and biometric variables. However, higher nutrient concentrations do not indicate better 
nutrition, since plants or plant organs that grow faster may exhibit lower nutrient concentrations due to dilution (Jarrell; Beverly 1981; Martinez et al., 2003; Prezotti; Bragança, 2013; Dubberstein et al., 2016; Dubberstein et al., 2019).

It is hypothesized that a higher nutrient supply allows greater concentration and accumulation in plant tissues up to an optimal limit. On the other hand, supplying more concentrated solutions may increase nutrient losses. Thus, nutrient concentration and accumulation were studied as well as macronutrient use efficiency in coffee seedlings (Coffea arabica) under daily fertigation with complete nutrient solutions and electrical conductivities of 1.0, 2.0 and $3.0 \mathrm{dS}$ $\mathrm{m}^{-1}$.

\section{MATERIAL AND METHODS}

Seeds were obtained from a Topázio cultivar coffee $(C$. arabica, originated from Catuaí amarelo and Mundo Novo, small size, medium fruit maturation and high productivity) crop in Uberaba, Minas Gerais (MG), Brazil, in May 2016. The seeds were extracted from fruits and germinated according Meireles et al. (2007) and adapted by Coelho et al. (2018). Seedlings with a $4 \mathrm{~mm}$ radicle were selected and planted in plastic cone-shaped containers $(120 \times 30 \mathrm{~mm}$ and volume of $50 \mathrm{~cm}^{3}$ ), filled with composted pine bark-based substrate (Bioplant $^{\circledR}$, minor components: sphagnum moss, coconut fiber, carbonized rice husk; properties: $\mathrm{pH}=6.5, \mathrm{EC}=0.8 \mathrm{mS} \mathrm{cm}{ }^{-1}$, maximum water retention $=100 \%$ ).

The experiment was carried out in a greenhouse covered with $50 \%$ shade cloth and transparent agricultural plastic film, between October 2016 and February 2017 (average maximum air temperature $=30.3{ }^{\circ} \mathrm{C}$, average minimum air temperature $=19.0{ }^{\circ} \mathrm{C}$, relative humidity $=73.6 \%$ and hours of sunlinght $=6.4$ hours day $^{-1}$ ) in Uberaba, MG. We used completely randomized design with four treatments and four replicates due to controlled experimental conditions. The treatments consisted of three complete nutrient solutions with electrical conductivities (EC) of 1.0, 2.0 and $3.0 \mathrm{dS} \mathrm{m}^{-1}$ and a non-fertilized control. The nutrient solution with EC of $1.0 \mathrm{dS}$ $\mathrm{m}^{-1}$ consisted of fertilizers with macronutrients ( $\mathrm{g} \mathrm{m}^{-3}$ of water): calcium nitrate (400), potassium nitrate (250), magnesium sulfate (175) and ammonium monophosphate (50), resulting in 91, 10, 101, 13, 91, 76, 16 and $21 \mathrm{mg} \mathrm{L}^{-1}$ of $\mathrm{N}^{-\mathrm{NO}^{-}}, \mathrm{N}_{3} \mathrm{NH}_{4}^{+}$, $\mathrm{N}$-total, $\mathrm{P}, \mathrm{K}, \mathrm{Ca}, \mathrm{Mg}$ and $\mathrm{S}$. A micronutrient source $(25 \mathrm{~mL}$ of ConMicros ${ }^{\circledR}$ Standard) was added (Allplant ${ }^{\circledR}, B=1.82 \%$, $\mathrm{CuEDTA}=1.82 \%, \quad$ FeEDTA $=7.26 \%, \quad \mathrm{MnEDTA}=1.82 \%$, $\mathrm{ZnEDTA}=0.73 \%, \mathrm{Mo}=0.36 \%, \mathrm{Ni}=0.335 \%$ ) per $\mathrm{m}^{3}$ of water. To obtain nutrient solutions of 2.0 and $3.0 \mathrm{dS} \mathrm{m}^{-1}$, the amount of fertilizer with macronutrients was doubled and tripled and micronutrient concentration remained constant.

After the nutrient solutions were prepared, the EC and $\mathrm{pH}$ of the following were measured using portable meters
(CD-203 and PH-100, Phtek $\left.^{\circledR}\right)$ : 1.0 EC solution $(\mathrm{pH}=6.7), 2.0$ EC solution $(\mathrm{pH}=6.5), 3.0 \mathrm{EC}$ solution $(\mathrm{pH}=6.2)$ and water $(\mathrm{EC}=0.08, \mathrm{pH}=6.9)$. The experimental plots consisted of 12 cone-shaped containers containing one coffee seedling each, arranged in plastic trays on benches $1 \mathrm{~m}$ above ground. They were irrigated daily with water or solutions manually with a plastic wash bottle $(500 \mathrm{~mL})$ using 80 to $100 \mathrm{~mL}$ of water or nutrient solution in each plot.

After the seedlings were planted on October 13, 2016, the cone-shaped containers were irrigated until October 26, when treatments began. After $1 \mathrm{~h}$ of treatments on February 13, 2017, two groups of four cone-shaped containers were randomly selected from each plot to measure EC and $\mathrm{pH}$ according to the 'PourThru' method (Cavins; Whipker; Fonteno, 2004). Each group of four cone-shaped containers was placed in a plastic container and the cone-shaped containers irrigated individually with distilled water using the wash bottle, until $50 \mathrm{~mL}$ of solution drained from the group was obtained. The samples were transferred to a beaker and the EC and $\mathrm{pH}$ measured. Each group of four cone-shaped containers was considered one sampling unit $(n=8)$.

The coffee seedlings were assessed 4 months after planting, on February 13, 2017, when they exhibited standard commercialization and planting characteristics. Eight of the 12 seedlings from the plot were assessed. After being removed from the cone-shaped containers in the laboratory, we separated the shoots (stem and leaves) from the roots with scissors. The shoot material from each plot was packed in a perforated plastic bag and dried in an air circulation oven at $65{ }^{\circ} \mathrm{C}$ until constant mass. The shoot dry mass of eight plants was determined on an analytical scale.

The dry mass of eight plants was used to obtain the total concentration of $\mathrm{N}$ (sulfuric acid digestion), $\mathrm{P}, \mathrm{K}, \mathrm{Ca}$, $\mathrm{Mg}, \mathrm{S}, \mathrm{Cu}, \mathrm{Fe}, \mathrm{Mn}$ and $\mathrm{Zn}$ (nitro-perchloric digestion) and $\mathrm{B}$ (azomethine $\mathrm{H}$ colorimetric). The accumulated amount of nutrient was calculated by the product of nutrient concentration and shoot dry mass of the plot. The recovery rate of six nutrients was calculated by dividing the accumulated amount in the shoot by the amount applied over 110 days of fertigation with a daily volume of $60 \mathrm{~mL}$ (average of $90 \mathrm{~mL}$ and $60 \mathrm{~mL}$ in 12 and eight cone-shaped containers, respectively).

The data were submitted to regression analyses with analysis of variance (F-test and p-value) and Scott-Knott means clustering $(\mathrm{p}<0.05)$ with $\mathrm{R}$ software $(\mathrm{R}$ core team, 2019).

\section{RESULTS}

The most concentrated nutrient solution reduced acidity $(\mathrm{F}=107.28, \mathrm{p}<0.0001)$ and linearly increased the $\mathrm{EC}$ of the drained solution in the cone-shaped containers $(\mathrm{F}=221.04, \mathrm{p}<0.0001)$ (Figure 1). The highest shoot dry mass 
values of coffee seedlings were observed in the treatments with a nutrient solution at EC of 1.0 and $2.0 \mathrm{dS} \mathrm{m}^{-1}$, with

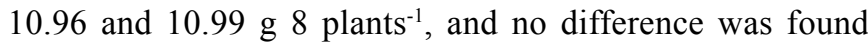
between them $(p=0.9429)$. The mass of seedlings that received a more concentrated nutrient solution $(\mathrm{EC}=3.0 \mathrm{dS}$ $\left.\mathrm{m}^{-1}\right)$ was higher $(9.95 \mathrm{~g})$ than that of non-fertilized seedlings $(1.73 \mathrm{~g})(\mathrm{p}<0.001)$.

The concentration of macronutrients $\mathrm{N}, \mathrm{P}, \mathrm{K}, \mathrm{Mg}$ and $\mathrm{S}$ in coffee seedling shoots was influenced by nutrient solutions with EC between 0 and $3 \mathrm{dS} \mathrm{m}^{-1}(\mathrm{p}<0.001)$, but not Ca concentration $(\mathrm{F}=1.49, \mathrm{p}=0.27)$ (Figure 2$)$. The treatments influenced the accumulated amount of six macronutrients (Figure 3). The concentrations of N, K and $\mathrm{S}$ increased linearly with a spike in the highest concentration of nutrient solutions. For macronutrient concentration, the lowest adjustment was observed for $\mathrm{N}\left(\mathrm{R}^{2}=0.9074\right)$, which varied from 12.3 to $34.8 \mathrm{~g} \mathrm{~N}$ per $\mathrm{Kg}$ of plant tissue. Macronutrients $\mathrm{P}$ and $\mathrm{Mg}$ exhibited quadratic responses to an increase in the $\mathrm{EC}$ of the nutrient solution. The concentration of $\mathrm{P}$ declined at $\mathrm{EC}$ of $1.0 \mathrm{dS} \mathrm{m}^{-1}\left(1.6 \mathrm{~g} \mathrm{~kg}^{-1}\right)$ in comparison to the control $\left(2.0 \mathrm{~g} \mathrm{Kg}^{-1}\right)$ (Figure 2).

With respect to macronutrient accumulation in the shoots of the seedlings (4 months), there were positive quadratic responses for $\mathrm{N}, \mathrm{P}, \mathrm{K}, \mathrm{Ca}$ and $\mathrm{Mg}$ to an increase in the EC of nutrient solutions and a positive linear response for $\mathrm{S}$ (Figure 3). The highest accumulated amounts of $\mathrm{P}, \mathrm{K}$ and $\mathrm{Ca}$ were observed at a nutrient solution EC of $2.0 \mathrm{dS} \mathrm{m}^{-1}$ and the highest $\mathrm{Mg}$ and $\mathrm{S}$ accumulation at $3.0 \mathrm{dS} \mathrm{m}^{-1}$ (Figure 3).

\section{$\hat{\mathrm{Y}}=-0.1356+1.125 \mathrm{X}\left(\mathrm{R}^{2} \mathrm{aj}=0.933\right)$}

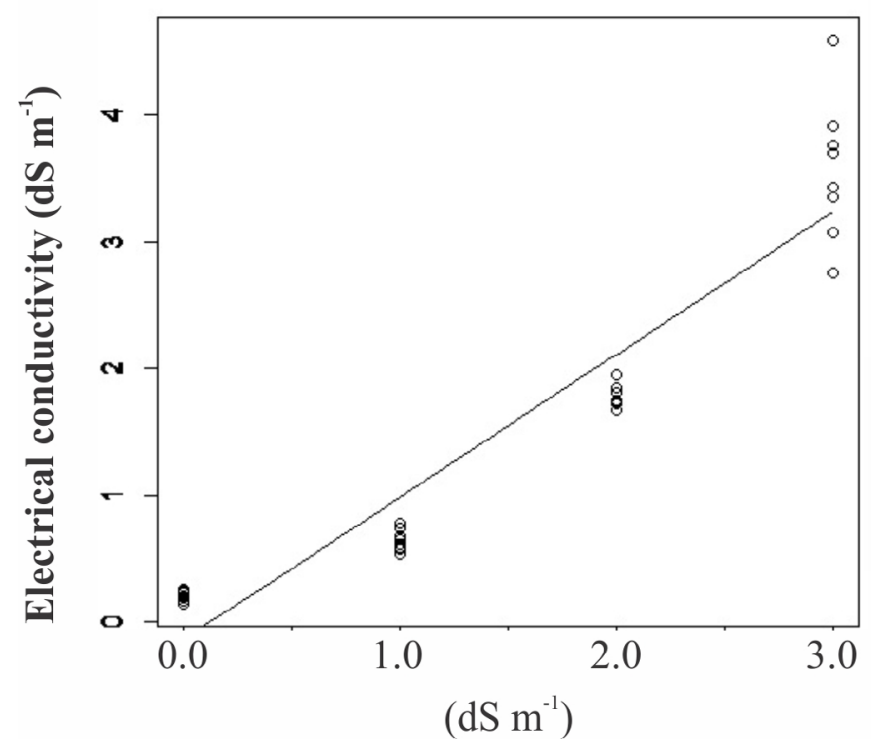

Regarding micronutrients, only Cu was not affected by nutrient solutions in terms of concentration $(\mathrm{F}=1.19, \mathrm{p}=0.3548)$ and accumulation $(\mathrm{F}=1.99, \mathrm{p}=0.1689)$. The concentration of $\mathrm{Mn}$ displayed the lowest response to the nutrient solutions applied $(\mathrm{F}=5.23$ and $\mathrm{p}=0.0153)$. The concentrations of $\mathrm{B}$ and Fe were higher in non-fertilized plants $\left(\mathrm{EC}=0.0 \mathrm{dS} \mathrm{m}^{-1}\right)$. By contrast, shoot $\mathrm{Zn}$ concentration was higher, with an increase in the concentration of nutrient solutions (Figure 4).

The accumulated amounts of $\mathrm{B}, \mathrm{Fe}, \mathrm{Mn}$ and $\mathrm{Zn}$ responded significantly to daily fertigation using nutrient solutions with different ECs and p-values $<0.0001$ (Figure 4). B, Fe, Mn and $\mathrm{Zn}$ exhibited quadratic responses and an increase in nutrient solution concentrations up to EC of $2.0 \mathrm{dS} \mathrm{m}^{-1}$. Adjusted coefficients of determination were above 0.9 for $\mathrm{B}, \mathrm{Mn}$ and $\mathrm{Zn}$ (Figure 4). Despite the significant effect of treatments on the amount of $\mathrm{Fe}$ in the seedlings $(\mathrm{F}=21.11$ and $\mathrm{p}<0.0001)$, the regression obtained exhibited low adjustment to the ECs of nutrient solutions $\left(\mathrm{R}^{2}=0.5476\right)$. The highest $\mathrm{Fe}$ accumulation was obtained with the nutrient solution at $\mathrm{EC}=1.0 \mathrm{dS} \mathrm{m}{ }^{-1}$ compared to seedlings submitted to more concentrated solutions (Figure 4).

The highest macronutrient use efficiencies by coffee seedlings were observed when fertilized by the nutrient solution at $\mathrm{EC}=1.0 \mathrm{dS} \mathrm{m}^{-1}$. With the intermediate concentration solution (2.0), $\mathrm{P}, \mathrm{K}, \mathrm{Ca}$ and $\mathrm{Mg}$ use efficiencies were higher than in the most concentrated nutrient solution (3.0). Use efficiency was around $40 \%$ for $\mathrm{N}$ and $\mathrm{K}, 20 \%$ for P, Ca and $\mathrm{Mg}$ and 5\% for S (Figure 5).

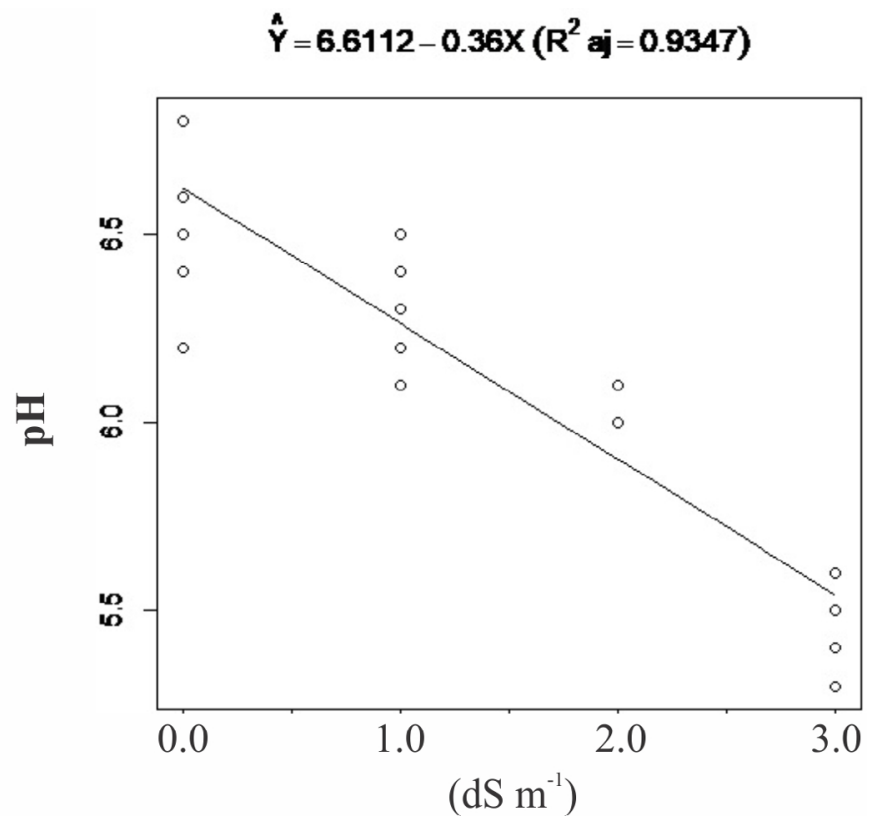

Figure 1: Adjusted regressions for electrical conductivity values ( $\mathrm{dS} \mathrm{m}^{-1}$ ) and $\mathrm{pH}$ of solutions drained from coffee (Coffea arabica) seedlings (120 days) under irrigation (0.0) or fertigation with electrical conductivity of 1.0; 2.0 and $3.0 \mathrm{dS}^{-1}$. ANOVA: Electrical conductivity: $F=221.04, p<0.0001 ; p H: F=107.28, p<0.0001$. 

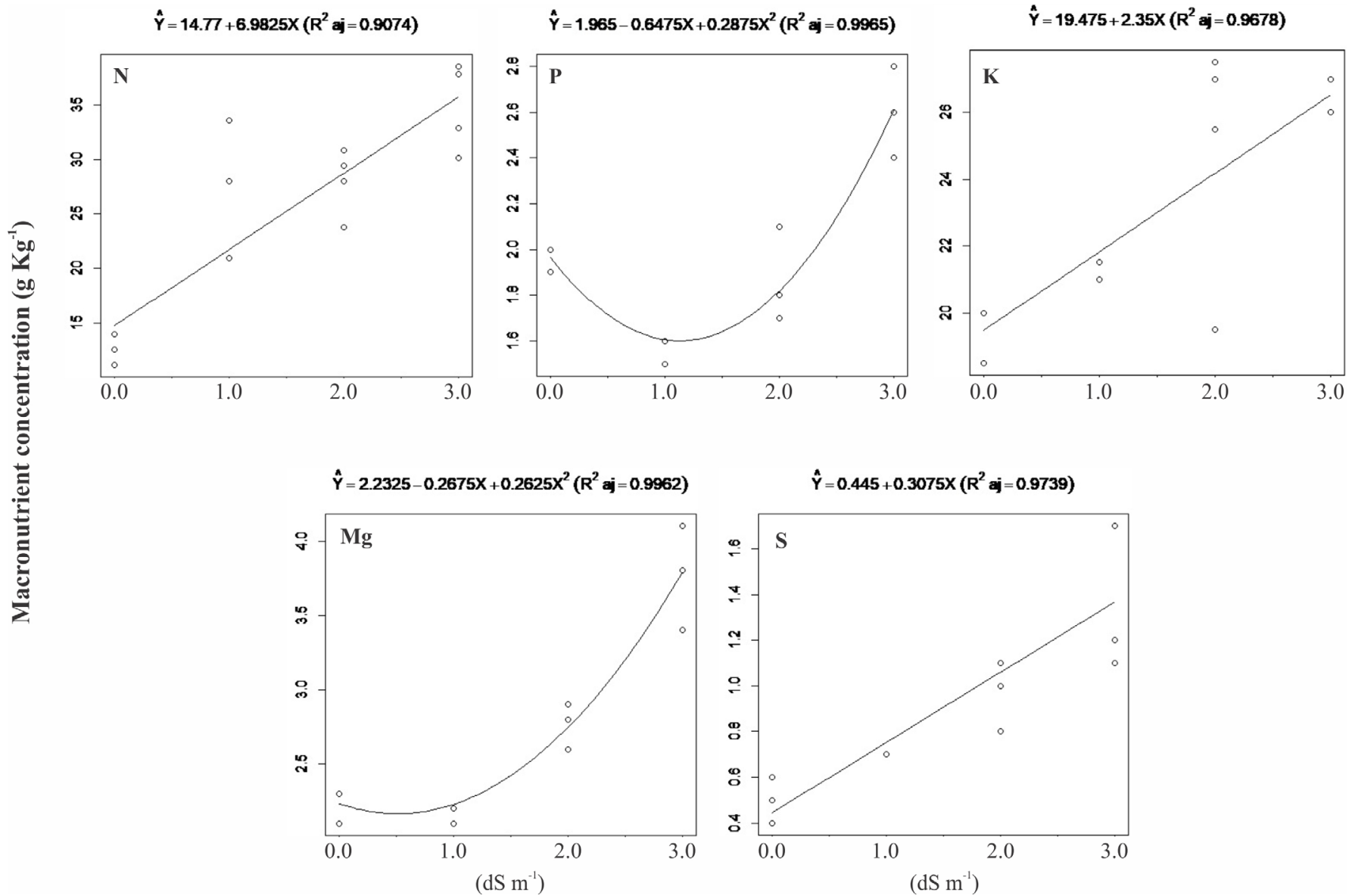

Figure 2: Adjusted regressions for macronutrient concentration in the shoots of eight coffee (Coffea arabica) seedlings (120 days) under irrigation (0.0) or fertigation with electrical conductivity of 1.0; 2.0 and $3.0 \mathrm{dS} \mathrm{m}^{-1}$. ANOVA: N: $F=22.28, p<0.0001 ; P$ : $F=48.76, p<0.0001 ; K: F=10.52, p=0.0011 ; M g: F=75.77, p<0.0001 ; S: F=20.05, p<0.0001$.

\section{DISCUSSION}

More concentrated fertigation solutions provided more nutrients to plants and exhibited higher acidity, since most fertilizing salts showed an acidic characteristic. Solutions with EC of $2 \mathrm{dS} \mathrm{m}^{-1}$ displayed a $\mathrm{pH}$ of around 7.0, while those with half this conductivity had a $\mathrm{pH}$ of 7.5 (Ludwig; Fernandes, 2013). The 'PourThru' method has proven to be adequate in assessing the $\mathrm{EC}$ and $\mathrm{pH}$ of fertigation solutions in substrates (Cavins; Whipker; Fonteno, 2004; Ludwig; Fernandes 2013).

The average macronutrient concentrations in the shoots of fertilized coffee seedlings $(\mathrm{EC}=1.0,2.0$ and 3.0 $\mathrm{dS} \mathrm{m}^{-1}$ ) revealed that $\mathrm{N}$ and $\mathrm{P}$ concentrations were lower in the present study than those found by Flores et al. (2016), whereas the concentration of $\mathrm{K}$ was higher and $\mathrm{Ca}, \mathrm{Mg}$ and $\mathrm{S}$ concentrations were similar in the two studies. The same occurred with the accumulated amounts of these three macronutrients. In this experiment, each coffee plant was grown in an 8-liter container in a closed hydroponic system. Despite the higher seedling dry mass (11.4 g plant $\left.^{-1}\right)$ obtained by Flores et al. (2016) than that observed in our study (1.4 $\left.\mathrm{g} \mathrm{plant}^{-1}\right)$, the $\mathrm{K}$ accumulated by the seedlings in the present study was higher $\left(82 \mathrm{mg}\right.$ seedling $\left.{ }^{-1}\right)$. Despite the differences in concentrations and accumulated amounts $(\mathrm{N}, \mathrm{P}$ and $\mathrm{K})$, the order of macronutrient accumulation was similar in the two studies: $\mathrm{N}>\mathrm{K}>\mathrm{Ca}>\mathrm{P}>\mathrm{Mg}>\mathrm{S}$.

Among the macronutrients, the fertigation solutions had no effect on $\mathrm{Ca}$ concentration. The effect of dilution on plant nutrition, as opposed to concentration, has been discussed and reviewed (Jarrell; Beverly, 1981). The increased biomass in conilon coffee plant berries (Coffea canephora) resulted in a decline in nutrient concentrations (Prezotti; Bragança, 2013). For Ca, Dubberstein et al. (2016) found a dilution effect in C. canephora berries. Diagnosis of the nutritional status of coffee seedlings should consider the effect of dilution since seedlings that grew the most (shoot dry mass of $11 \mathrm{~g} 8$ plants $^{-1}$ ) exhibited the same shoot $\mathrm{Ca}$ concentrations as those that grew the least $(1.7 \mathrm{~g})$. Moreover, shoot $\mathrm{Ca}$ concentrations (9-10 $\mathrm{g} \mathrm{Kg}^{-1}$ ), with and without fertigation, were higher than those suggested by Gonçalves et al. (2009), who considered leaf concentrations between 6.9 and $7.6 \mathrm{~g} \mathrm{Kg}^{-1}$ adequate for this nutrient. 
$\hat{\mathrm{Y}}=33.7796+268.4459 \mathrm{X}-56.2419 \mathrm{X}^{2}\left(\mathrm{R}^{2}\right.$ aj $\left.=0.951\right)$

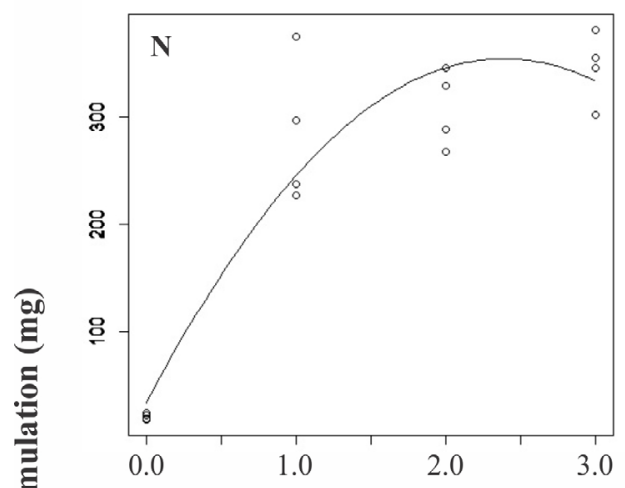

$\hat{\mathrm{Y}}=20.2235+85.1123 \mathrm{X}-19.9088 \mathrm{X}^{2}\left(R^{2} \mathrm{aj}=0.9265\right)$

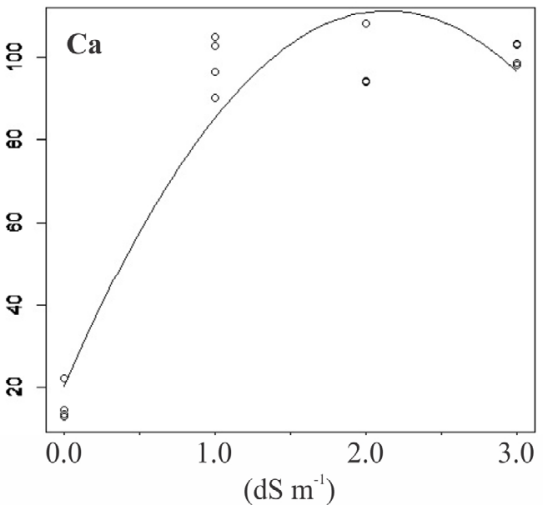

$\hat{\mathrm{Y}}=4.0713+13.2888 \mathrm{X}-2.0787 \mathrm{X}^{2}\left(\mathrm{R}^{2}\right.$ aj $\left.=0.9679\right)$

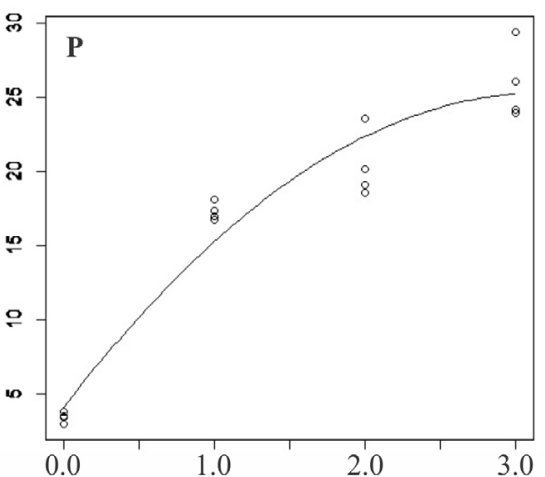

$\hat{\mathrm{Y}}=4.5295+20.7407 \mathrm{X}-3.3213 \mathrm{X}^{2}\left(\mathrm{R}^{2} \mathrm{aj}=0.9872\right)$

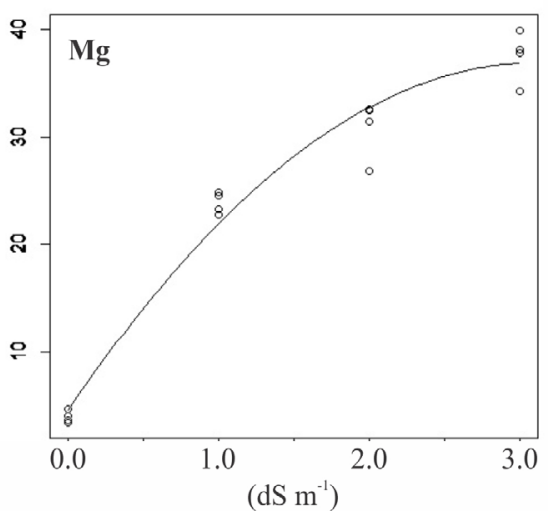

$\hat{\mathrm{Y}}=39.0691+231.8079 \mathrm{X}-53.1769 \mathrm{X}^{2}\left(\mathrm{R}^{2} \mathrm{aj}=0.9861\right)$

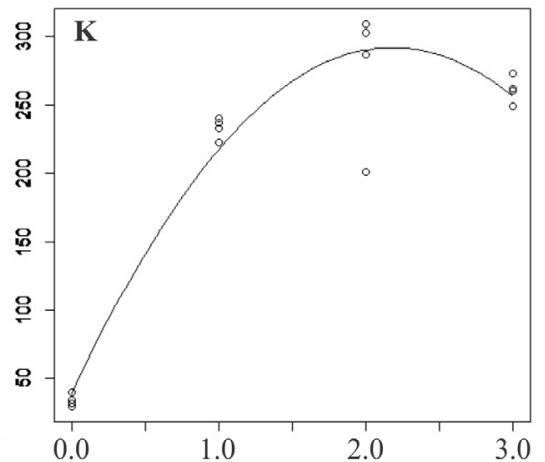

$\hat{\mathrm{Y}}=1.9285+4.3572 \mathrm{X}\left(\mathrm{R}^{2} \mathrm{aj}=0.9621\right)$

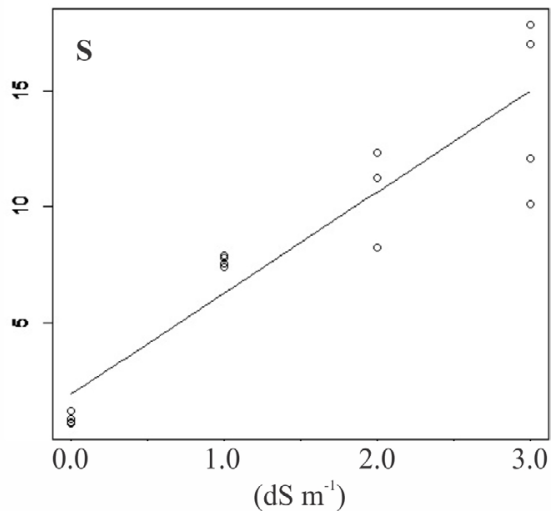

Figure 3: Adjusted regressions for macronutrient accumulation in the shoots of eight coffee (Coffea arabica) seedlings (120 days) under irrigation (0.0) or fertigation with electrical conductivity of $1.0 ; 2.0$ and $3.0 \mathrm{dS} \mathrm{m}^{-1}$. ANOVA: N: $F=50.00, p<0.0001 ; P$ : $F=123.66, p<0.0001 ; \mathrm{K}: F=75.45, p<0.0001$; $\mathrm{Ca}: F=233.70, p<0.0001 ; \mathrm{Mg}: F=235.28, p<0.0001 ; \mathrm{S}: F=29.40, p<0.0001$.

Nutrient solutions with different ECs (from 1.0 to 4.0 $\mathrm{dS} \mathrm{m}^{-1}$ ) caused significant differences in concentrations of $\mathrm{N}$, $\mathrm{P}, \mathrm{K}, \mathrm{Ca}$ and $\mathrm{S}$ in potato leaves under a hydroponic system, but $\mathrm{Mg}$ concentration was not affected by fertigation (Calori et al., 2017). In the present study, shoot Ca concentrations were similar between fertilized and non-fertilized seedlings, irrespective of the EC of the nutrient solution applied.

Quadratic curves for the accumulation of N, P, K and $\mathrm{Ca}$ in $\mathrm{C}$. arabica shoots, with a maximum fertigation point of $2.0 \mathrm{dS} \mathrm{m}^{-1}$, indicate that this EC should be the nutrient solution limit for this specie. Considering eight growth variables, the best $C$. arabica cv. Topázio seedling development occurs with complete nutrient solutions between 1.4 and $2.2 \mathrm{dS} \mathrm{m}^{-1}$ (Coelho et al., 2018).

In addition to the amount of nutrients supplied in fertigation, the ionic species must be considered. The fertigations studied are nitrate-based, exhibiting a

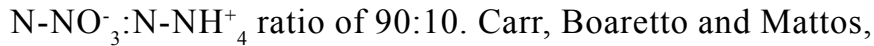
(2020) found that yellow $C$. arabica cv. Catuaí seedlings in a hydroponic system displayed better photosynthetic capacity and nutrient absorption in solutions with

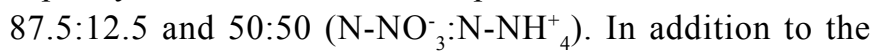
ionic form, the relationship between the nutrients may affect the susceptibility of coffee plants to diseases. In $C$. arabica seedlings, the higher $\mathrm{K}$ : Ca ratio $\left(6-7 \mathrm{mmol} \mathrm{L}^{-1}: 2\right.$ mmol L-1) reduced the incidence of leaf spots caused by Phoma tarda (Catarino et al., 2016).

The amount of micronutrients supplied to plants was the same in fertigations with $1.0,2.0$ and $3.0 \mathrm{dS} \mathrm{m}^{-1}$. The micronutrients $\mathrm{Cu}, \mathrm{Fe}, \mathrm{Mn}$ and $\mathrm{Zn}$ were supplied as EDTA chelates. However, fertilizers altered the $\mathrm{pH}$ of the solution in the substrate, which affected the micronutrient concentration in $C$. arabica seedlings. Acidification of the nutrient solution increased $\mathrm{Fe}, \mathrm{Cu}$ and $\mathrm{Zn}$ concentration in the leaves of $C$. arabica seedlings (Carr; Boaretto; Mattos, 2020). In the present study, the highest accumulation of $B$, $\mathrm{Mn}$ and $\mathrm{Zn}$ occurred in the nutrient solution of $2.0 \mathrm{dS} \mathrm{m}^{-1}$ with intermediate $\mathrm{pH}$ of 6.0 in the drained solution. At the lowest $\mathrm{pH}$ (5.4), B, Fe, Mn and $\mathrm{Zn}$ accumulation declined in the seedling shoots. 

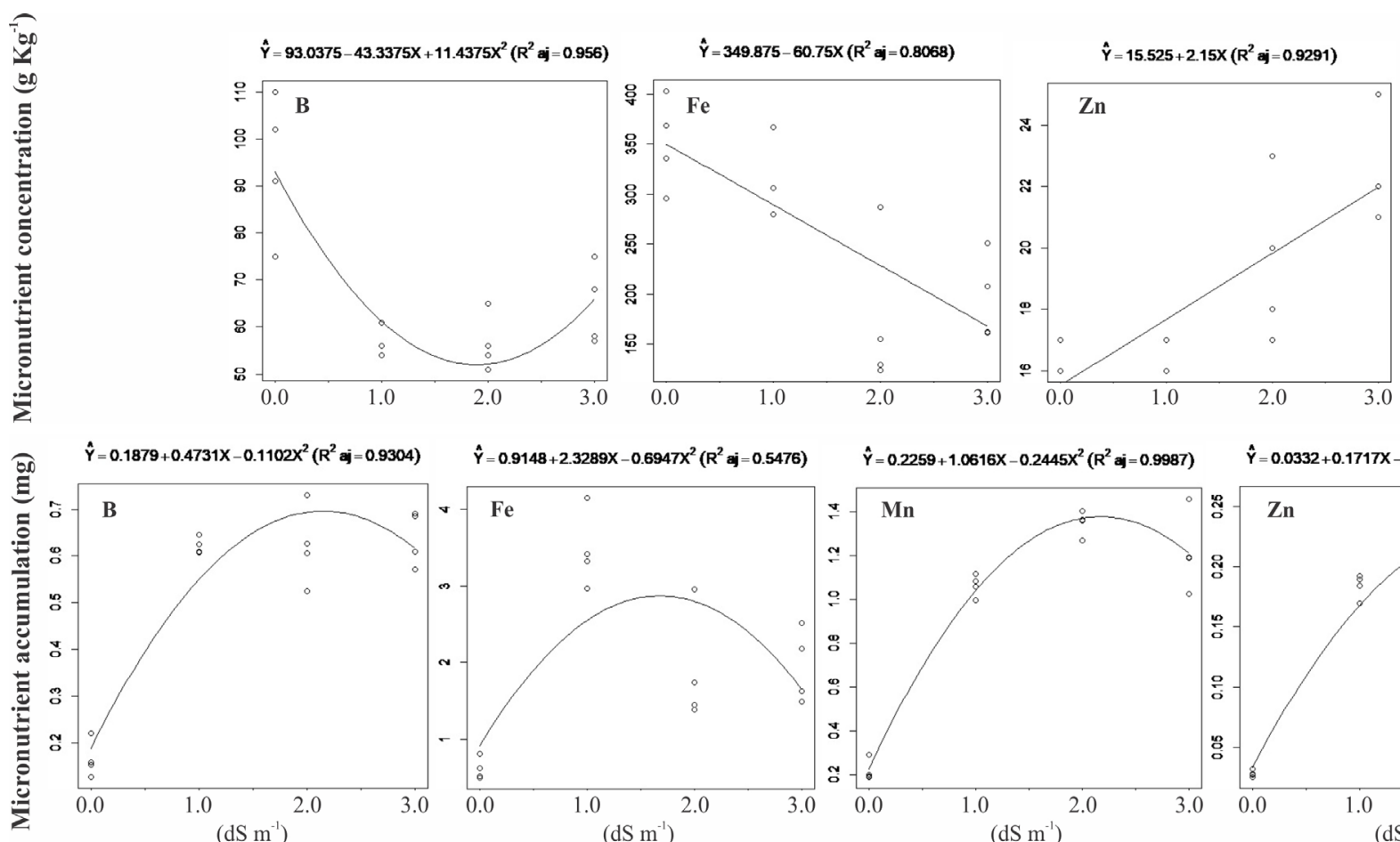

Figure 4: Adjusted regressions for micronutrient concentration and micronutrient accumulation in the shoots of eight coffee (Coffea arabica) seedlings (120 days) under irrigation (0.0) or fertigation with electrical conductivity of $1.0 ; 2.0$ and $3.0 \mathrm{dS} \mathrm{m}^{-1}$. ANOVA: concentration - B: $F=14.89, p=0.0002$; Fe: $F=10.90, p=0.0010 ; Z n: F=12.64, p=0.0005$. ANOVA: accumulation - B: $F=69.04, p<0.001 ; F e: F=21.11, p<0.001 ; M n: F=103.26, p<0.001 ; Z n: F=81.13, p<0.001$.
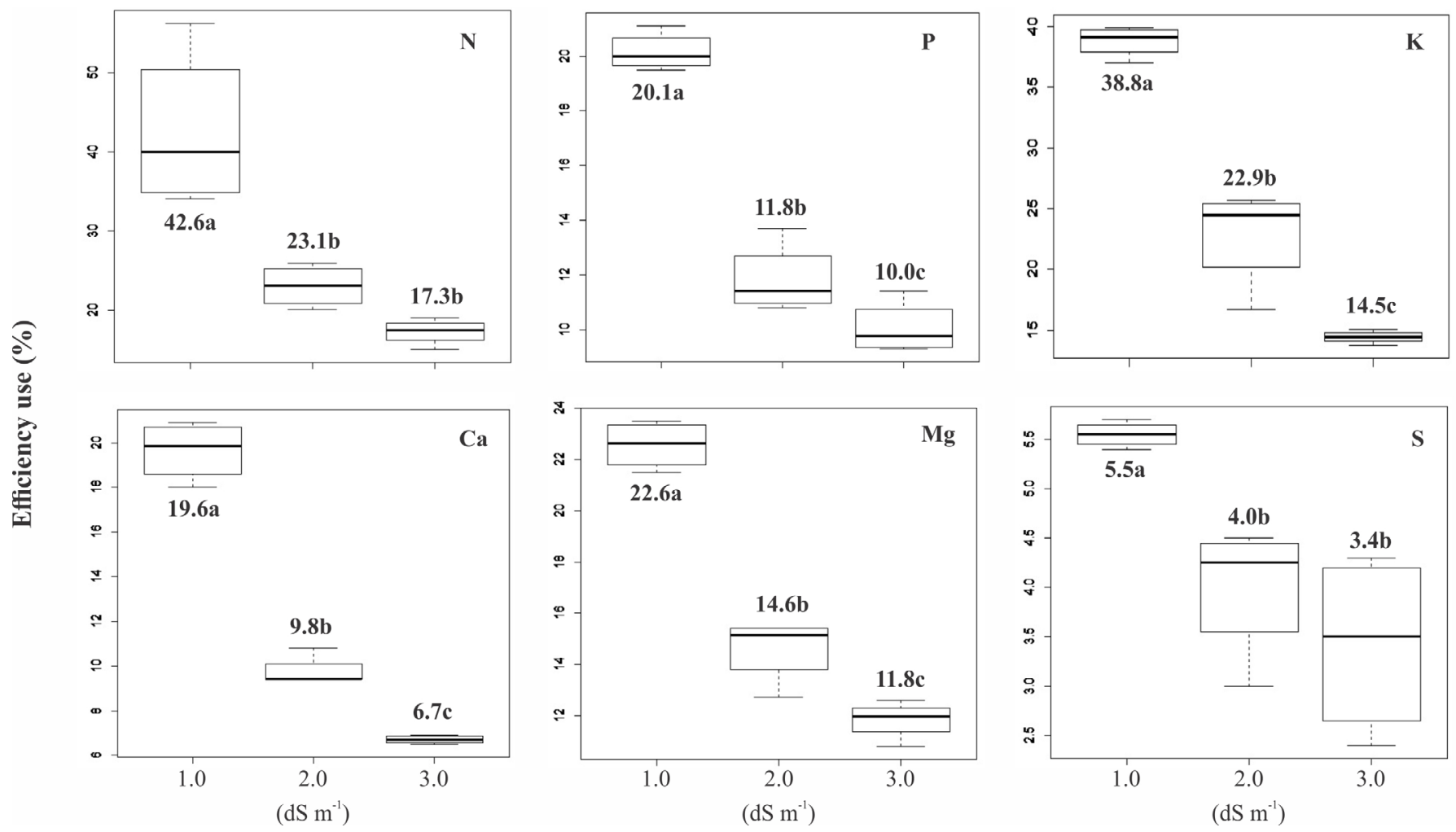

Figure 5: Box-plot graphs of macronutrient recovery rates by the shoots of eight coffee (Coffea arabica) seedlings (120 days) under fertigation with electrical conductivity of 1.0; 2.0 and $3.0 \mathrm{dS} \mathrm{m}^{-1}$. ANOVA: N: F=18.67, $p<0.001 ; \mathrm{P}: \mathrm{F}=111.75, \mathrm{p}<0.001 ; \mathrm{K}$ : $F=94.53, p<0.001$; Ca: $F=243.38, p<0.001$; $\mathrm{g}: F=120.62$, $p<0.001 ; S: F=10.83, p<0.001$. Means with the same letter and nutrient are not significantly different according to the Scott-Knott test $(p<0.05)$. 
In a closed hydroponics system, absorption of micronutrients $\mathrm{B}, \mathrm{Zn}, \mathrm{Cu}$ and $\mathrm{Mn}$ in coffee plants was less than $1 \%$ of the total provided, and the translocation of these nutrients was between $60 \%$ and $90 \%$ (Ferreira et al., 2013). In the present study, micronutrient use efficiency was not estimated because the amounts applied were the same between treatments. However, a positive effect was observed with an increase in macronutrient concentration $\left(2.0 \mathrm{dS} \mathrm{m}^{-1}\right)$ in the nutrient solution and the $\mathrm{pH}(6.0)$ on the $\mathrm{B}, \mathrm{Fe}, \mathrm{Mn}$ and $\mathrm{Zn}$ accumulation in $C$. arabica shoots.

The presence of $\mathrm{Si}$ may affect micronutrient concentration in different parts of the coffee plant shoots. Although $\mathrm{Si}$ does not change macronutrient content and accumulation, it decreases the $\mathrm{Zn}$ in roots and $\mathrm{Cu}$ in leaves and increases $\mathrm{Mn}$ in the stem, for both the concentration and amount of accumulated nutrient. The absence of an effect on macronutrients and the erratic effect of $\mathrm{Si}$ on micronutrients demonstrate that there was no nutritional benefit of $\mathrm{Si}$ for coffee seedlings (Cunha et al., 2012).

Fertigation with less concentrated nutrient solutions is cheaper than more concentrated counterparts. In addition to the better cost-benefit, less concentrated fertigation results in enhanced macronutrient use efficiencies. The recovery rates of citrus seedlings ( 8 months) with fertigation of 2.0 $\mathrm{dS} \mathrm{m}^{-1}$ in the substrate were $34,23,12,26,9$ and $9 \%$ for $\mathrm{N}$, $\mathrm{P}, \mathrm{K}, \mathrm{Ca}, \mathrm{Mg}$ and $\mathrm{S}$, respectively (Boaventura et al., 2004). Higher efficiencies were obtained with coffee seedlings for $\mathrm{N}(43 \%), \mathrm{K}(39 \%)$ and $\mathrm{Mg}(23 \%)$. The use efficiencies of $\mathrm{P}$ and $\mathrm{Ca}$ were similar (around 20\%) and those of S lower in the present study $(5 \%)$.

\section{CONCLUSIONS}

The dynamics of nutrient absorption, translocation and incorporation in plants is primarily affected by plant metabolism and nutrient availability in the root environment. By growing the plants without soil, nutrient solutions previously used exclusively in research began to be modified and studied to be compatible with new cropping systems. Since then, low-cost nutrient solutions have been sought after, thereby allowing good plant development with more efficient nutrient use. Biometric growth parameters and the amount of nutrients in plant tissues have been used to measure mineral nutrition performance in soilless cultivation. In $C$. arabica seedlings, the response to the increase in $\mathrm{Ca}$ in the nutrient solution is evident in the accumulation of this nutrient in the plant but not its concentration, possibly because of the dilution effect. Micronutrient accumulation in this species (except $\mathrm{Cu}$ ) is also more adequate for determining nutritional status in these plants than its concentration. Moreover, a rise in macronutrient concentration in the nutrient solution increases B, Fe, Mn and $\mathrm{Zn}$ accumulation. In addition to increasing the cost of the production system in general, applying more concentrated macronutrient solutions acidifies the root environment and reduces nutrient efficiency, thereby raising environmental contamination.

\section{ACKNOWLEDGMENTS}

This research was supported by Professional Master Program in Plant Production of Instituto de Ensino Ciência e Tecnologia do Triângulo Mineiro - Campus Uberaba, Brazil.

\section{AUTHORS' CONTRIBUTION}

PEBP and VPMC designed experiments; KMR and HLBA performed experiments; PEBP analyzed the data and wrote the paper; KMR, PEBP, VPMC, MC and HLBA cowrote the paper, review and approval of the final version of the work.

\section{REFERENCES}

ADAMS, C.; FRANTZ, J.; BUGBEE, B. Macro and micronutrient-release characteristics of three polymercoated fertilizers: Theory and measurements. Journal of Plant Nutrition and Soil Science, 176(1):76-88, 2013.

BOAVENTURA, P. R. R. et al. Balanço de nutrientes na produção de mudas cítricas cultivadas em substrato. Revista Brasileira de Fruticultura, 26(2):300-305, 2004.

BROSCHAT, T. K. Nitrate, phosphate, and potassium leaching from container-grown plants fertilized by several methods. HortScience, 30(1):74-77, 1995.

CALORI, A. H. et al. Electrical conductivity of the nutrient solution and plant density in aeroponic production of seed potato under tropical conditions (winter/spring). Bragantia, 76(1):23-32, 2017.

CARR, N. F.; BOARETTO, R. M.; MATTOS, D. Coffee seedlings growth under varied $\mathrm{NO}_{3}^{-}: \mathrm{NH}_{4}^{+}$ratio: Consequences for nitrogen metabolism, amino acids profile, and regulation of plasma membrane $\mathrm{H}^{+}$ -ATPase. Plant Physiology and Biochemistry, 154:1120,2020 .

CATARINO, A. M. et al. Calcium and potassium contents in nutrient solution on Phoma leaf spot intensity in coffee seedlings. Revista Ceres, 63(4):486-491, 2016.

CAVINS, T. J.; WHIPKER, B. E.; FONTENO, W. C. Establishment of calibration curves for comparing pourthrough and saturated media extract nutrient values. HortScience, 39(7):1635-1639, 2004. 
COELHO, V. P. M. et al. Fertigation and growth regulator on coffee seedling production in tubes. Pesquisa Agropecuária Tropical, 48(4):350-357, 2018.

CUNHA, A. C. M. C. M. et al. Growth and nutrient uptake of coffee seedlings cultivated in nutrient solution with and without silicon addition. Revista Ceres, 59(3):392-398, 2012.

DUBBERSTEIN, D. et al. Concentration and accumulation of macronutrients in leaf of coffee berries in the Amazon, Brazil. Australian Journal of Crop Science, 10(5):701$710,2016$.

DUBBERSTEIN, D. et al. Concentration and accumulation of micronutrients in robust coffee. Acta Scientiarum Agronomy, 41:e42685, 2019.

FERREIRA, A. D. et al. Dinâmica dos micronutrientes em cafeeiros enxertados. Revista Ceres, 60(2):262-269, 2013.

FLORES, R. A. et al. Growth and nutritional disorders of coffee cultivated in nutrient solutions with suppressed macronutrients. Journal of Plant Nutrition, 39(11):1578-1588, 2016.

GONÇALVES, S. M. et al. Faixas críticas de teores foliares de macronutrientes em mudas de cafeeiro (Coffea arabica L.) produzidas em tubetes. Ciência e Agrotecnologia, 33(3):743-752, 2009.
JARRELL, W. M.; BEVERLY, R. B. The dilution effect in plant nutrition studies. In: BRADY, N. C. Advances in agronomy. New York: Academic Press, p. 197-224, 1981.

LUDWIG, F.; FERNANDES, D. M. Electrical conductivity and $\mathrm{pH}$ of the substrate solution in gerbera cultivars under fertigation. Horticultura Brasileira, 31(3):356-360, 2013.

MARTINEZ, H. E. P. et al. Coffee-tree floral analysis as a mean of nutritional diagnosis. Journal of Plant Nutrition, 26(7):1467-1482, 2003.

MEIRELES, R. C. et al. Secafé: Metodologia para acelerar a germinação das sementes de café. Revista Brasileira de Sementes, 29(3):90-96, 2007.

PREZOTTI, L.; BRAGANÇA, S. Acúmulo de massa seca, N, $\mathrm{P}$ E K em diferentes materiais genéticos de café conilon. Coffee Science, 8(3):284-294, 2013.

R CORE TEAM. R: A language and environment for statistical computing. R Foundation for Statistical Computing version 3.5.3. 2019. Vienna, Austria. Available in: http://www.R-project.org/>. Access in: November, 03, 2019.

SILVA, P. C. R. et al. Slow release fertilizers or fertigation for sugarcane and passion fruit seedlings? Agronomic performance and costs. Journal of Soil Science and Plant Nutrition, 20:2175-2181, 2020. 